\title{
Pengaruh Motivasi dan Dukungan Keluarga terhadap Prestasi Belajar Mahasiswa Tingkat II Prodi D-III Kebidanan Universitas Ubudiyah Indonesia
}

\author{
The Effect of Motivation and Family Support on Learning Achievement of D-III \\ Product Level II Students of Ubudiyah Indonesia University
}

\author{
Faradilla Safitri*1 $^{1}$, Cut Yuniwati ${ }^{2}$ \\ ${ }^{1}$ UniversitasUbudiyah Indonesia, Jln. Alue Naga DesaTibang,KecamatanSyiah Kuala, Banda Aceh, Indonesia \\ ${ }^{2}$ Poltekkes Kemenkes Aceh, Lambaro, Aceh Besar, Indonesia ${ }^{2}$ \\ *Korespondensi Penulis faradilla@uui.ac.id
}

\begin{abstract}
Abstrak
Prestasi belajar merupakan tingkat kemanusiaan yang dimiliki siswa dalam menerima, menolak, dan menilai informasi yang diperoleh dalam proses belajar mengajar. Tujuan penelitian ini untuk mengetahui pengaruh motivasi dan dukungan keluarga terhadap prestasi belajar mahasiswa tingkat II Prodi D-III Kebidanan Universitas Ubudiyah Indonesia. Jenis penelitian ini bersifat analitik dengan pendekatan cross sectional. Teknik pengambilan sampel total sampling sebanyak 73 orang. Instrumen penelitian menggunakan kuesioner dan transkrip nilai. Hasil penelitian analisis ini menunjukkan bahwa ada pengaruh motivasi terhadap prestasi belajar mahasiswa dengan nilai $\mathrm{P}$-Value $=0,000(\mathrm{P}<0,05)$ dan ada pengaruh dukungan keluarga terhadap prestasi belajar mahasiswa dengan nilai P-Value $=0,000(\mathrm{P}<$ 0,05). Berdasarkan hasil penelitian dapat disimpulkan bahwa ada pengaruh yang signifikan antara motivasi dan dukungan keluarga terhadap prestasi belajar mahasiswa.
\end{abstract}

Kata kunci: Motivasi, dukungan keluarga, prestasi belajar

\begin{abstract}
Learning achievement is the level of humanity that students have in accepting, rejecting, and assessing information obtained in the teaching and learning process. The purpose of this study was to determine the effect of motivation and family support on the learning achievements of second-level students of Midwifery Diploma III Study Program at Ubudiyah University in Indonesia. This type of research is analytical with a cross sectional approach. The total sampling technique is 73 people. The research instrument used a questionnaire and value transcript. The results of this analysis show that there is an effect of motivation on student learning achievement with a P-Value value $=0,000(P<0.05)$ and there is an influence of family support on student learning achievement with a $P$-Value $=0,000(P$ $<0.05)$. Based on the results of the study it can be concluded that there is a significant influence between motivation and family support for student learning achievement.
\end{abstract}

Keywords: Motivation, family support, learning achievement. 


\section{PENDAHULUAN}

Prestasi belajar merupakan tingkat kemanusiaan yang dimiliki siswa dalam menerima, menolak, dan menilai informasi-informasi yangdiperoleh dalam proses belajar mengajar. Prestasi belajar seseorang sesuai dengan tingkat keberhasilan sesuatu dalam mempelajari materi pelajaran yang dinyatakan dalam bentuk nilai setelah mengalami proses belajar(Ardimoviz, 2012). Prestasi belajar siswa dipengaruhi oleh dua faktor utama yaitu faktor internal adalah faktor yang timbul dari dalam diri individu itu sendiri, diantaranya adalah minat, bakat, motivasi dan tingkat intelegensi. Faktor yang kedua yaitu faktor eksternal adalah segala bentuk pengaruh yang datang dari luar diri dan mempengaruhi kegiatan belajar seseorang, diantaranya adalah keluarga, sekolah dan faktor sosial (Slameto, 2005).

Azwar (2009) juga menambahkan bahwa banyak faktor yang mempengaruhi keberhasilan dalam proses pembelajaran, diantaranya motivasi belajar. Motivasi belajar sangat penting untuk menghindari para mahasiswa dari kegagalan. Motivasi adalah dorongan individu atau seseorang untuk berbuat/mengerjakan sesuatu dengan tujuan memenuhi kebutuhannya. Motivasi merupakan faktor pendorong manusia untuk bertingkah laku didalam mencapai kebutuhan atau sesuatu yang dicita-citakan. Menurut Hamzah (2009), motivasi dapat diterapkan dalam berbagai kegiatan, tidak terkecuali belajar, motivasi dalam belajar sangatlah penting dikarenakan pengaruh untuk perbuatan belajar kepada tujuan yang jelas yang diharapkan dapat tercapai. Motivasi merupakan suatu tenaga potensi untuk menjadikan perilaku atau tindakan, sedangkan motivasi merupakan pengerahan dan penguatan motif itu untuk diaktualisasikan diri dalam perbuatan nyata, dalam kaitannya dengan perilaku maka motif dan motivasi itu tidak dapat dipisahkan sehingga akan muncul konsep motivasi akan mencakup motif dan penguatan.

Penelitian Wasty Soemanto (2003) menyebutkan, pengenalan seseorang terhadap prestasi belajarnya adalah penting, karena dengan mengetahui hasil-hasil yang sudah dicapai maka siswa akan lebih berusaha meningkatkan prestasi belajarnya. Dengan demikian peningkatan prestasi belajar dapat lebih optimal karena siswa tersebut merasa termotivasi untuk meningkatkan prestasi belajar yang telah diraih sebelumnya.

Biggs dan Tefler (dalam Dimyati dan Mudjiono, 2006) mengungkapkan motivasi belajar siswa dapat menjadi lemah. Lemahnya motivasi atau tiadanya motivasi belajar akan melemahkan kegiatan, sehingga mutu prestasi belajar akan rendah. Oleh karena itu, mutu prestasi belajar pada siswa perlu diperkuat terus menerus dengan tujuan agar siswa memiliki 
motivasi belajar yang kuat, sehingga prestasi belajar yang diraihnya dapat optimal. Nurkholis (2006) menambahkan bahwa dalam lingkungan keluarga setiap individu atau siswa memerlukan dukungan orang tua dalam mencapai prestasi belajar, karena dukungan dan perhatian keluarga ini akan menentukan seseorang siswa dapat mencapai prestasi belajar yang tinggi. Dukungan keluarga diwujudkan dalam hal kasih sayang, memberi nasehat-nasehat dan sebagainya.

Slameto (2005) mengatakan, untuk mengetahui hasil prestasi belajar yang dicapai siswa diadakan penilaian. Penilaian dapat diadakan setiap saat selama kegiatan berlangsung, dapat juga diadakan setelah siswa menyelesaikan program pembelajaran dalam waktu tertentu, misalnya per semester dan dilihat dari IP maupun IPK siswa tersebut. Berdasarkan survei yang dilakukan di Prodi D-III Kebidanan Universitas Ubudiyah Indonesia, didapatkan jumlah total mahasiswa Prodi D-III Kebidanan tingkat II (dua) sebanyak 73 yang dibagi dalam 2 kelas, yaitu kelas II A sebanyak 35 orang dan kelas II B sebanyak 38 orang. Indeks Prestasi Kumulatif (IPK) rata-rata 2.74dengan IPK $\geq 2,75$ sebanyak $49 \%$ dan IPK <2,75 sebanyak $51 \%$.Sesuai dengan buku Pedoman Akademik Universitas Ubudiyah Indonesia menyebutkan bahwa peserta didik yang memiliki hasil nilai akhir dengan Indeks Prestasi Akademik (IPK) <2,75, maka peserta didik tersebut tidak dapat mengikuti sidang tugas akhir (Karya Tulis Ilmiah) dan tidak dapat dinyatakan lulus dari perkuliahannya.

\section{METODE PENELITIAN}

Jenis penelitian ini bersifat analitik yaitu untuk mengetahui pengaruh antara variabel dependent dan variabel independent, dengan pendekatan cross sectional yaitu penelitian yang dikumpulkan dalam waktu bersamaan. Teknik pengambilan sampel dalam penelitian ini adalah total sampling yaitu 73 orang. Instrumen penelitian menggunakan kuesioner dan transkrip nilai mahasiswi, cara pengumpulan data dengan cara membagikan kuesioner. Analisis data menggunakan analisis univariat dan bivariate. 


\section{HASIL DAN PEMBAHASAN}

Tabel 1. Pengaruh Motivasi Terhadap Prestasi Belajar Mahasiswa Tingkat II Prodi D-III Kebidanan Universitas Ubudiyah Indonesia

\begin{tabular}{|c|c|c|c|c|c|c|c|c|}
\hline \multirow{3}{*}{ No } & \multirow{3}{*}{ Motivasi } & \multicolumn{4}{|c|}{ Prestasi Belajar } & \multirow{2}{*}{\multicolumn{2}{|c|}{ Jumlah }} & \multirow{3}{*}{ P-Value } \\
\hline & & \multicolumn{2}{|c|}{ Tinggi } & \multicolumn{2}{|c|}{ Rendah } & & & \\
\hline & & $\mathbf{f}$ & $\%$ & $\mathbf{f}$ & $\%$ & $\mathbf{n}$ & $\%$ & \\
\hline 1 & Tinggi & 36 & 66,7 & 18 & 33,3 & 54 & 100 & \multirow{2}{*}{0,000} \\
\hline 2 & Rendah & 0 & 0 & 19 & 100 & 19 & 100 & \\
\hline
\end{tabular}

Berdasarkan Table. 1 dapat disimpulkan bahwa dari 54 responden yang memiliki motivasi tinggi serta prestasi belajarnya tinggi ada 36 orang (66,7\%). Hasil uji statistik didapatkan nilai P-Value $=0,000(\mathrm{P}<0,05)$, maka Ho ditolakdan Ha diterima, jadi dapat disimpulkan bahwa ada pengaruh yang signifikan antara motivasi dengan prestasi belajar mahasiswa.

Tabel 2. Pengaruh Dukungan Keluarga Terhadap Prestasi Belajar Mahasiswa Tingkat II Prodi D-III Kebidanan Universitas Ubudiyah Indonesia

\begin{tabular}{|c|c|c|c|c|c|c|c|c|}
\hline \multirow{3}{*}{ No } & \multirow{3}{*}{ Dukungan Keluarga } & \multicolumn{4}{|c|}{ Prestasi Belajar } & \multirow{2}{*}{\multicolumn{2}{|c|}{ Jumlah }} & \multirow{3}{*}{ P-Value } \\
\hline & & \multicolumn{2}{|c|}{ Tinggi } & \multicolumn{2}{|c|}{ Rendah } & & & \\
\hline & & $\mathbf{f}$ & $\%$ & $\mathbf{f}$ & $\%$ & $\mathbf{n}$ & $\%$ & \\
\hline 1 & Ada & 35 & 74,4 & 12 & 25,6 & 47 & 100 & \multirow{2}{*}{0,000} \\
\hline 2 & Tidak Ada & 1 & 3,9 & 25 & 96,1 & 26 & 100 & \\
\hline
\end{tabular}

Berdasarkan Table. 2 dapat disimpulkan bahwa dari 47 responden yang mendapatkan dukungan keluarga serta miliki prestasi belajarnya tinggi ada 35 orang (74,4\%). Hasil uji statistik didapatkan nilai P-Value $=0,000(\mathrm{P}<0,05)$, maka Ho ditolak dan Ha diterima, jadi dapat disimpulkan bahwa ada pengaruh yang signifikan antara dukungan keluarga dengan prestasi belajar mahasiswa.

\section{Pembahasan}

1. Pengaruh Motivasi terhadap Prestasi Belajar

Hasil penelitian diatas sesuai dengan pendapat Azwar (2009) yang menyatakan bahwa banyak faktor yang mempengaruhi keberhasilan dalam proses pembelajaran, diantaranya motivasi belajar. Motivasi belajar sangat penting untuk menghindari para 
mahasiswa dari kegagalan. Motivasi adalah dorongan individu atau seseorang untuk berbuat/mengerjakan sesuatu dengan tujuan memenuhi kebutuhannya. Motivasi merupakan faktor pendorong manusia untuk bertingkah laku didalam mencapai kebutuhan atau sesuatu yang dicita-citakan. Djiwandono (2006) juga menambahkan bahwa motivasi adalah salah satu prasyarat yang amat penting dalam belajar. Gedung dibuat, guru disediakan, alat belajar lengkap dengan harapan supaya siswa masuk sekolah dengan semangat. Tetapi semua itu sia-sia, jika siswa tidak ada motivasi untuk belajar.

Berdasarkan penelitian yang telah dilakukan dari 54 responden yang memiliki motivasi belajar yang tinggi terdapat $18(33,3 \%)$ responden memiliki prestasi belajar yang rendah, hal ini disebabkan karena untuk peningkatan prestasi belajar bukan hanya dari segi motivasinya saja, namun prestasi belajar dikatakan sempurna (tinggi) apabila memenuhi tiga aspek yakni aspek kognitif, afektif dan psikomotor. Dari hasil penelitian juga didapat bahwa 19 responden yang memiliki motivasi yang rendah serta prestasi belajar yang rendah pula, hal ini disebabkan karena masih kurangnya minat mahasiswa untuk mencari informasi-informasi terbaru tentang perkuliahan serta kurang bersemangatnya mahasiswa ketika diberikan penugasan oleh dosen untuk melakukan diskusi dikelas, karena mahasiswa khawatir tidak bisa menjawab pertanyaan yang akan diajukan oleh teman-temannya sehingga mereka malu dan menjadi malas untuk melakukan diskusi di kelas.

Peneliti berasumsi bahwa motivasi berfungsi untuk menimbulkan, mendasari dan mengarahkan perbuatan belajar. Motivasi dapat menentukan baik atau tidaknya dalam mencapai tujuan, sehingga semakin besar kesuksesan belajarnya. Seseorang yang besar motivasinya akan giat berusaha, tampak gigih, tidak mau menyerah dan giat membaca buku-buku untuk meningkatkan prestasinya. Lain halnya apabila motivasi belajar melemah maka mutu prestasi belajar akan menjadi rendah, oleh karena itu mutu prestasi belajar pada mahasiswa perlu diperkuat terus menerus dengan tujuan agar mahasiswa memiliki motivasi belajar yang kuat sehingga prestasi belajar yang diraihnya dapat optimal.

2. Pengaruh Dukungan Keluarga terhadap Prestasi Belajar

Hasil penelitian ini ejalan dengan penelitian Witriani (2007) yang menujukkan bahwa, hal-hal yang bersifat eksternal seperti keberadaan orang lain (dukungan orang tua, 
dalam bentuk pacar, teman yang membantu belajar/diskusi) lebih dipandang sebagai faktor yang membantu kelancaran studi.

Hasil penelitian diatas sesuai dengan pendapat Nurkholis (2006) yang menjelaskan bahwa dalam lingkungan keluarga setiap individu atau siswa memerlukan dukungan orang tua dalam mencapai prestasi belajar, karena dukungan dan perhatian keluarga ini akan menentukan seseorang siswa dapat mencapai prestasi belajar yang tinggi. Dukungan keluarga diwujudkan dalam hal kasih sayang , memberi nasehat-nasehat dan sebagainya.

Friedman (2000) menjelaskan bahwa dukungan keluarga adalah sikap, tindakan dan penerimaan terhadap tiap-tiap anggota keluarga. Anggota keluarga memandang bahwa orang yang bersifat mendukung selalu siap memberikan pertolongan dan bantuan jika dibutuhkan. Berdasarkan penelitian yang dilakukan dari 47 responden yang memiliki dukungan keluarga, didapat $12(25,6 \%)$ memiliki prestasi belajar yang rendah. Hal tersebut disebabkan karena untuk peningkatan prestasi belajar bukan hanya dukungan keluarga, namun lingkungan sekolah dan lingkungan masyarakat juga berperan penting dalam peningkatan prestasi belajar mahasiswa.

Dari hasil penelitian juga didapatkan 25 responden yang tidak memiliki dukungan keluarga serta memiliki prestasi belajar yang rendah, hal tersebut dikarenakan orang tua tidak pernah menghubungi/berdiskusi dengan dosen pembimbing untuk menanyakan tentang kemajuan perkuliahan anaknya dan ketika anaknya mendapatkan nilai yang baik, ada beberapa orang tua yang tidak memberikan selamat ataupun tidak memberikan penghargaan kepada anaknya agar sang anak merasa senang dan dihargai sehingga anak dapat lebih giat lagi dalam belajarnya. Peneliti berasumsi bahwa dukungan keluarga merupakan sebuah proses yang terjadi disepanjang masa kehidupan yang memiliki banyak fungsi yaitu dukungan informasional dengan manfaat dapat menyumbangkan aksi sugesti yang khusus pada mahasiswa berupa nasehat, usulan, saran, petunjuk dan pemberian informasi. Dukungan penilaian yang bertindak sebagai membimbing dan menengahi pemecahan masalah, memberikan penghargaan dan perhatian.

Dukungan instrumental yang bertindak sebagai sumber penolong praktis dan kongkrit dalam hal kebutuhan hidup dan dukungan emosional yang berguna sebagai tempat yang aman dan damai berkat adanya kepercayaan, perhatian, mendengarkan dan didengarkan. Dengan dukungan yang diberikan oleh keluarga, maka mahasiswa akan lebih giat dalam belajar sehingga dapat meninggkatkan prestasi belajarnya dan begitu pula 
sebaliknya, apabila mahasiswa tidak mendapatkan dukungan dari keluarga maka ia merasa tidak dibutuhkan dan tidak memiliki semangat untuk dalam proses belajarnya, sehingga hasil prestasi belajarnya menjadi rendah.

\section{KESIMPULAN}

Berdasarkan peneltian dapat disimpulkan bahwa ada pengaruh motivasi terhadap prestasi belajar mahasiswa tingkat II Prodi D-III Kebidanan Universitas Ubudiyah Indonesia dengan nilai $\mathrm{P}$-Value $=0,000(\mathrm{P}<0,05)$ dan ada pengaruh dukungan keluarga terhadap prestasi belajar mahasiswa tingkat II Prodi D-III Kebidanan Universitas Ubudiyah Indonesia dengan nilai $\mathrm{P}-$ Value $=0,000(\mathrm{P}<0,05)$.

\section{SARAN}

Penelitian ini dapat menjadi bahan bacaan untuk meningkatkan motivasi serta mengetahui tentang pentingnya dukungan keluarga dalam meningkatkan prestasi belajar; Penelitian ini dapat menjadi informasi kepada peneliti lain tentang pentingnya motivasi dan dukungan keluarga dalam proses belajar untuk meningkatkan prestasi belajar serta dapat melakukan penelitian lanjutan dengan variabel yang berbeda; Penelitian ini dapat menjadi bahan informasi dan masukan bagi institusi dalam hal penyelenggaraan kegiatan belajar mengajar yang lebih efektif dan efisien dalam memotivasi mahasiswa dalam belajar serta mendapatkan dukungan keluarga guna meningkatkan prestasi belajar mahasiswa.

\section{UCAPAN TERIMA KASIH}

Ucapan terima kasih kepada Universitas Ubudiyah Indonesia yang telah memberikan dukungan financial dalam penelitian ini dan ucapan terimakasih kepada mahasiswi prodi D-III Kebidanan Tingkat II yang telah bersedia menjadi responden selama penelitian.

\section{DAFTAR PUSTAKA}

Azwar. (2009). Prinsip-prinsipKesehatan. Jakarta : Bina rupa Aksara.

Dimyati dan Mudjiono. (2006). Belajar dan Pembelajaran. Jakarta : PT. Raja grafindo Persada.

Friedman. (2000) Peningkatan Motivasi dan Keaktifan dalam Pembelajaran. Jakarta : PT Gramedia Widiasarana. 
Hamzah. (2009) Teori Masalah dan Pengukurannya Analisis di Bidang Pendidikan. Jakarta: Bumi Aksara.

Slameto.(2005). Belajar dan Faktor-Faktor yang Mempengaruhinya. Jakarta : Rhineka Cipta.

Wasty Soemanto. (2003). Psikologi Pendidikan. Malang: Rineka Cipta.

Witriani, dkk. (2007). Instrumen Pengukuran Motivasi dan Rancangan Intervensi. Fakultas Psikologi Universitas Padjadjaran. 